\title{
Geographical Concepts in Turkish Lullabys
}

\author{
Taner Çifçi
}

Faculty of Education, Cumhuriyet University, Turkey

Copyright $\subset 2016$ by authors, all rights reserved. Authors agree that this article remains permanently open access under the terms of the Creative Commons Attribution License 4.0 International License

\begin{abstract}
In this study, a collection of lullabies which have an important place in Turkish culture and which form an important genre in folk literature are examined to find out distribution and presentation of geographical terms in the lullabies in this collection. In the study, 2480 lullabies in Turkish Lullabies [10] which is one of the leading collections in Turkey and 1320 lullabies, which were still being collected when the study was conducted, have been examined. These lullabies were accepted as linguistic sample of the study. Content analysis and discourse analysis were used in the study. Lullabies were transformed to the computers, their word counts and lists have been obtained. Among these words, the one related to geography were grouped and content analysis was conducted. Later on, the lullabies were submitted to content analysis, and the researcher depicted how geographical terms were presented. Results of the study indicated that approximately $10 \%$ of the words in the lullabies are related to geography. The lullabies presented environmental and geographic information from immediate environment to remote environment and starting from concrete and experiences. In the respects, lullabies can be used as instructional materials to teach geography to children aged 0 to 6 . It is suggested that lullabies should be collected, saved and used in education as primary source of information in linguistic development and in other fields in pre-school period.
\end{abstract}

Keywords Geography, Turkish Lullabies,
Geographical Concepts

\section{Introduction}

Geography is a discipline which examines natural, human and economic events on earth, and which establishes relation between these events and environment and human beings and the distribution of these events on earth within the framework of causal [32]. It is necessary to learn geography to understand and analyze the place of universal concepts in the universe and the hegemony of the powers that use them [5]. In this context, it is possible to understand the order in earth and foresee indecisiveness, crises and chaos [13].
However, when doing them, just like other disciplines, geography, which studies the relation between human and nature, also makes use of various branches of science. Education and literature are also among these.

While education is defined as a process of creating desirable changes in human behaviors [12]; Kavcar [21] stated that the most important functions of education are to help individual to accommodate the society and age $\mathrm{s} / \mathrm{he}$ lives in, to introduce and infuse social values and national values of the past generations, and to help him/her acquire sets of values and skills. In all periods of an individual's life, these functions influence human life and cognitive development through education. These functions of education are especially prominent in early childhood, childhood, adolescence and in early youth. The age period between 0 and 6 as one of the periods of human development when children develop very fast cognitively, socially and physically influences their future lives [27]. In this period, children perceive and recognize their immediate social and physical environments [30]. Preschool Curriculum in Turkey was implemented to ensure that children attending preschool educational institutions grow up healthily with rich learning experiences, they reach the highest level by supporting every area of development, they gain self-care skills and they are prepared for the basic education [1]. In the next period, education prepares the individual for future and the society $\mathrm{s} /$ he lives, and the requirements for this function and socialization function of education are fulfilled are fulfilled both at school and in the society. At schools and formal educational institutions, this function is fulfilled at schools in a programmed way and under the control and surveillance of the government. In general, this kind of education provided to train individuals and society that will conform to the needs of the modern world and the ideal of state to bring up good citizens is mentioned in and shaped by official regulations.

Education also informally fulfills it socialization function and brings up individuals as good representatives of society in the society with its own unique methods and means. In this sense, the child conforms to the community s/he live in throughout his/her life and learns and adopts its values, judgments, history, customs, traditions, social structure and social relations and roles, and transmits them to the next generation. In this way, this educational setting which is 
informally shaped, and which changes and develops within the society's own dynamics allows the preservation and sustainment of the social structure and transmission of the same structure to the next generations. In this type of education, which is also called as informal education, the society makes use of abstract and concrete means which have been structured as a result of various processes. With these means, culture, information, emotions and feelings are transferred. Carpets, shelters, clothes can be given as examples of concrete means and linguistic ones which include poems, folk songs, sagas, idioms, beliefs are examples of abstract means.

Human beings use linguistic and psychological concepts, symbols, numbers and words when they are socializing and communicating. Some of these means are transmitted from one generation to another generation in certain patterns, expressions and as written or oral literary works. Especially in folk literature, these elements make up the folkloric part of culture. One of the most important works of folk literature, which are passed on from one generation to another are lullabies. When we examine definitions of lullaby, we see that such characteristics are emphasized "they are rhyming and melodic works of poems with certain formulaic words added and which are song for children by their parents, relatives or caretakers in tune to silence them or to put them to sleep" [22].

The lullabies stand out as the most important children's literature and pre-school educational materials and techniques in Turkish culture. In this regard, pre-school education in Turkish cultures starts with lullabies song when children are babies in bundles [10]. By using a pure and lucid Turkish with simple and eclectic words, basic elements and concepts which are to be given in pre-school education besides mother tongue education are given via lullabies. When the distribution of basic concepts and objects presented in lullabies is considered, it is seen that they include elements from many fields in life. Lullabies emphasize many concepts and values from immediate environment and life to the ideals of a nation [10]. Singing children lullabies with music or melody not only leads to learning by addressing to minds of children but also makes children happy $[18,19]$. Lullabies are special kind of songs which have lived up to now over centuries and among cultures and which are used to soothe, put to sleep and silence [17].

Besides helping children develop taste of music and sensitivity, one outstanding function of lullabies as a genre of anonymous folk literature and children's literature is their contribution to socialization of children and to their preparation for life in the future. It is known that human beings think by establishing relations between physical environment, social milieu, society and cognitive functions and also using symbols $[3,4,28]$. That is to say, beginning with their birth human beings build constructs in their minds using their experiences and through these constructs they acquire new knowledge, and learn how to conform to social norms and about other events in their life; they assess them and internalize or reject new knowledge or values. The constructs that human beings develop in their minds can be a bundle of knowledge, a criterion of assessment, attitudes or values. These affect human beings lives and forms their knowledge stores or personalities by accumulating in time. Lullabies form the genre in which human being face knowledge and values for the first time. With lullabies, human beings establish connections with the culture and society in which they live and try to acquire social legacy.

Lullabies are mostly sung to put babies to sleep or sometimes sung at their side when babies wake up. Lullabies which are generally sung by the mother or a female with unique melody help relaxing and shooting babies psychologically and physically [20]. Besides, lullabies contribute to linguistics, cognitive, emotional and physical development of children [21]. A human being learns his/her mother tongue with stories, sagas, manis (quatrains in folk music), lullabies, proverbs, and reduplications. In this respect, others' influence on child's language is directly correlated with their relations with the child [2]. In other words, lullabies not only develop the baby linguistically but also help him/her acquire his/her mother tongue [14].

Although not directly related to geography, there are relevant studies on lullabies. Tsang \& Conrad [34], studied the messages lullabies give as songs. Trehub \& Trainor [33], studied lullabies as a means mothers use to transmit culture. Yet another study in the field of music is carried out by Cooper \& Aslin [7]. Demir \& Oflaz [11] studied using lullabies to teach math in pre-school period. Çelebioğlu [8] wrote the book the Treasure of Turkish Lullabies. Demir [9] and Lickteig \& Danielson [26] studied lullabies as a means of cultural transmission.

It can be argued that geography education starts in babyhood period and lullabies are one of the important sources through which this education can be given. However, it is seen that there are inadequate number of studies on the educational value of lullabies. This study which examines the use of Turkish lullabies in geography education, which have attracted the attention of researchers in recent years, will be one of the pioneering studies in this field. In this respect, it is considered that this study will both fill a gap and contribute to literature.

\section{Statement of the Problem}

The aim of this study is to determine to what extent and how geographical concepts, words, objects and expressions are used in lullabies which are one of the important elements of Turkish culture. In this framework, the study seeks to answer the following questions:

1) How are geographical concepts and words distributed in Turkish lullabies?

2) How are concepts and words presented in the lullabies?

\section{Materials and Methods}

In this study, 2480 lullabies in the book Turkish lullabies, 
which is one of the major lullaby collection in Turkey [10] and 1320 lullabies, which were being collected when this study was conducted. Total number of words in these lullabies is 25.186 . Two techniques were used in the analysis. First of all, the words used in lullabies were handled as qualitative data and submitted content analysis. Content analysis involves systematic examination of the content of a text via rule-based coding [6, 23, 35]. Stacey [29] defines content analysis as examination of text by transforming qualitative linguistic element or data into quantitative form. In short, content analysis is assessing and examining written or spoken discourse with their own context [16].

Lullabies were transferred to electronic medium (as Microsoft Word document) and analyzed using Word Power software. Among these words, the ones related to geography were chosen by the researcher and saved. During this selection, the words were analyzed together with the lullabies in which they occurred by two experts (one scholar who is expert in linguistics and one who is expert in geography) and their views were taken. The words that achieved $70 \%$ and over agreement between assessors were included in the analysis as inter-rater agreement between 0.61 and 0.80 is adequate for reliability $[24,25,36]$. In this way, validity was achieved. The words chosen in this way were analyzed with content analysis. Accordingly, a corpus composed of 3800 lullabies and 25.816 words has been analyzed. In 980 of these lullabies, 2645 words related to geography -including repetitions as well- have been determined. When the total number of words is considered, the rate of geography related words makes up $10 \%$. As a result of analysis of these words, 326 geography related words and concepts have been determined. Later on, the frequency and percentages of these words were found and results were interpreted.
Secondly, lullabies in which these words passed have been examined with -descriptive- discourse analysis technique. Discourse analyses are qualitative studies which examine any discourse (visual, written or spoken) from various aspects like the context, the intention and aims of speaker, how it is perceived by the speaker or listener and which make interpretation [16]. In line with the aims of this study, discourse analysis was employed to determine what kind of information lullabies, which are already determined in terms of context and aims- include and how this information is presented in lullaby. In this analysis, basically in relation to geography, the aims for singing a specific lullaby, its possible contributions to the child, relations with social life, fiction and real life. To this end, the lullabies in which the words the researcher and experts in the field determined are used have been examined and how these words are presented in each lullaby have been discussed and interpretations were made under the lullabies. Samples of these lullabies and interpretations are also given in this study. Under each lullaby, the names of the informant, the city of the lullaby and page numbers are given.

\section{Findings}

\subsection{Findings Related to the First Sub-problem}

In this section, answer for the first sub-problem "How are geographical concepts and words distributed in Turkish lullabies?" was sought. To this end, first of all the quantitative distribution of words has been examined and the words were determined and grouped under various headings related to geography. Accordingly, when the words in the lullabies are examined, it is seen that there are following groups of words related to geography (Table 1).

Table 1. Geography related words in lullabies and their groups

\begin{tabular}{|c|c|}
\hline Groups & Words \\
\hline Settlement and Space & $\begin{array}{c}\text { Housetop, funnel, house, city, country, state, neighborhood room, ceiling, brink, door, land on, migrate, market } \\
\text { place, tableland, crowd, nomad camping site, oven, carve, tent, school, class, country, foreign land, fountain, field, } \\
\text { nest etc... }\end{array}$ \\
\hline Land forms and Waters & $\begin{array}{l}\text { Mountain, stream, brook, slope, hill, Bosporus, tableland, gateway, land, fountain, river, meadow, square, zone, } \\
\text { country, valley, desert, lake, island, terrace, coast, shore, sea, ocean, pit and mound... }\end{array}$ \\
\hline Plants & $\begin{array}{l}\text { Flower, tree, pine, nut, fruit, forest, corn, poplar, leaf, root, elaeagnus, vine, lentil, walnut, apple, rose, branch, } \\
\text { apricot, cabbage, willow, chestnut, barley, fig, cane, melon, rice, wild pear, plum, lemon, daisy, quince, mint, } \\
\text { strawberry, zucchini, bud, rosebud, clover, almond, pepper weed, daffodil, plane tree, pepper, crop, barley, wheat, } \\
\text { chickpea, seed etc. }\end{array}$ \\
\hline Animals & $\begin{array}{l}\text { Calf, lamb, mutton, crow, cow, ox, goat, kid, cat, dog, cub, baby, grouse, wolf, rooster, hen, chick, pullet, camel, } \\
\text { donkey, colt, hound, goose, duck, crane, gazelle, horse, foal, deer, fox, nightingale, peacock, snake, bat, lion, fish, } \\
\text { turtle dove, partridge, pigeon, bee, fly, butterfly etc. }\end{array}$ \\
\hline Climate and Weather events & Breeze, rain, cool, cold, hot, warm, hail, snow, frost, cloud, wind, storm, flood etc. \\
\hline Time or season & $\begin{array}{c}\text { Spring, morning, evening, summer, winter, day, night, mid-morning, dawn, day, hour, early, late, before noon and } \\
\text { afternoon etc. }\end{array}$ \\
\hline Mine and precious Stones & Copper, golden, stone, pearl, diamond, coal etc. \\
\hline Universe and Space & The Pleiades, the Venus, the Milk Way, the moon, universe, star, the sun and the like... \\
\hline Agriculture and Husbandry & $\begin{array}{l}\text { orchard, calf, field, plow, crop, harvest, plough, ox, cow, mutton, goat, barley, wheat, seed storehouse, haymow, } \\
\text { cultivation, mow, seed, cutting firewood, herd mutton, yoghurt, milk, cheese, slurry, fold, kid, foal, lamb, horse, } \\
\text { donkey, colt, shovel, pickaxe, axe, hatchet, reaping-hook, scythe, onion, garlic etc. }\end{array}$ \\
\hline
\end{tabular}


In this section, the number of words and concepts related to geography, the most common three words and concepts are grouped and interpreted.

Table 2. Settlement and Space words and concepts in lullabies

\begin{tabular}{|c|c|c|}
\hline Word or Concept & f & $\%$ \\
\hline Housetop & 67 & 22 \\
\hline house & 51 & 16 \\
\hline Funnel & 21 & 7 \\
\hline Others & 167 & 55 \\
\hline Total & 306 & 100 \\
\hline
\end{tabular}

Geography examines the formation of settlements, their development, distribution, origins, changes and their relationships with places. Thus settlement geography has emerged to investigate the natural and human environment of the settlements and their relations.

According to findings given in Table 2, among Settlement and Space related words the word housetop is repeated 67 times $(22 \%)$, the Word house is repeated 51 times $(16 \%)$ and the Word funnel is repeated 21 times (7\%). However, it is seen that other words are like city, country, state, neighborhood room, ceiling, brink, door, land on, migrate, market place, tableland, crowd, nomad camping site, oven, carve, tent, school, class, country, foreign land, fountain, field, nest are repeated $167(55 \%)$ in lullabies. When children are born, they find themselves in their rooms and houses, which is called as micro-environment. They can have the opportunity get more closely acquainted with spaces with lullabies sung to them. They can be aware of the events in their environment with their knowledge and interest in living spaces.

Table 3. Word and concepts in lullabies related to Land forms and Waters

\begin{tabular}{|c|c|c|}
\hline Word or Concept & f & $\%$ \\
\hline Mountain & 51 & 25 \\
\hline Stream & 26 & 13 \\
\hline Brook & 24 & 12 \\
\hline Others & 104 & 50 \\
\hline Total & 205 & 100 \\
\hline
\end{tabular}

Physical geography examines lands and their formations where the atmosphere and earth surface verge. In Table 3, the classifications were made from this perspective.

As it can be seen in table 3, words or concepts related land forms and waters used in lullabies the word mountain is repeated 51 times $(25 \%)$, the word stream is repeated 26 times $(13 \%)$ and the word brook is used 24 times $(12 \%)$. However, other land forms 104 times (50\%) (slope, hill, Bosporus, tableland, gateway, land, fountain, river, meadow, square, zone, country, valley, desert, lake, island, terrace, coast, shore, sea, ocean, pit and mound etc.) in lullabies. Geography of Anatolia is rich in land forms and natural formations. In this context, it is considered that lullabies play a great role in introducing them to children from as early as babyhood period. Through lullabies children's curiosity about geography is satisfied to some extent and for the first time.

Table 4. Plant names and related concepts in lullabies

\begin{tabular}{|c|c|c|}
\hline Word or Concept & $\mathrm{f}$ & $\%$ \\
\hline Pine & 86 & 21 \\
\hline Tree & 82 & 20 \\
\hline Flower & 62 & 15 \\
\hline Other & 176 & 44 \\
\hline Total & 406 & 100 \\
\hline
\end{tabular}

Plant geography as a branch of geography describes plants, their distribution around the world and the various factors affecting the distribution of them.

According to the data presented in Table 4, among the plant names and related concepts, the word pine is repeated 86 times $(21 \%)$, tree is repeated 82 times $(20 \%)$, the Word flower is repeated 62 times $(15 \%)$. However, other words are repeated 176 times (44\%) in the lullabies (nut, fruit, forest, corn, poplar, leaf, root, elaeagnus, vine, lentil, walnut, apple, rose, branch, apricot, cabbage, willow, chestnut, barley, fig, cane, melon, rice, wild pear, plum, lemon, daisy, quince, mint, strawberry, zucchini, bud, rosebud, clover, almond, pepper weed, daffodil, plane tree, pepper, crop, barley, wheat, chickpea, seed etc...). It can be said that all children are interested in plants. However, it is considered that children have their first opportunity to get acquainted and learn types of plant. In this context, lullabies play significant roles in getting acquainted with natural environment and its elements.

Table 5. Animal names and related concepts in lullabies

\begin{tabular}{|c|c|c|}
\hline Word or concept & $\mathrm{f}$ & $\%$ \\
\hline Calf & 210 & 32 \\
\hline Lamb & 88 & 14 \\
\hline Mutton & 74 & 11 \\
\hline Other & 275 & 43 \\
\hline Total & 647 & 100 \\
\hline
\end{tabular}

Animal geography, examines the distribution of animals on earth. Animal and human relations have been a subject of attention from the first person. This situation has had cultural reflections. Lullabies are also one of the areas experiencing the culture of this reflection

According to findings in Table 5, among animal names or related concepts in lullabies, the word calf is repeated 210 $(32 \%)$, the Word lamb is repeated 88 times $(14 \%)$ and the word mutton is repeated 74 times $(11 \%)$. However, it was determined that other animal names and related concepts are repeated 275 times (43\%) in the lullabies. (crow, cow, ox, goat, kid, cat, dog, cub, baby, grouse, wolf, rooster, hen, chick, pullet, camel, donkey, colt, hound, goose, duck, crane, gazelle, horse, foal, deer, fox, nightingale, peacock, snake, bat, lion, fish, turtle dove, partridge, pigeon, bee, fly, 
butterfly etc.). Animals have always attracted children's attention. According to the findings, animals like calf, lamb and mutton come to the forth in lullabies. This is attributed to the animal population in the immediate environment Thus, in lullabies animals are presented to the children according to educational principles.

Table 6. Word and concepts related to climate and weather events in lullabies

\begin{tabular}{|c|c|c|}
\hline Word or Concept & $\mathrm{f}$ & $\%$ \\
\hline Wind & 21 & 22 \\
\hline Rain & 16 & 17 \\
\hline Cool & 16 & 17 \\
\hline Other & 43 & 44 \\
\hline Total & 96 & 100 \\
\hline
\end{tabular}

The purpose of the climatology as one of sub-disciplines of geography is to examine climate types, the effects of climate natural and human environment. Climate and weather events have affected human life continuously. This interaction affects lifestyles, values, attitudes, and directly reflected in the culture and other facts and events.

According to Table 6 in which the frequency of words or concepts related to climate and weather events in lullabies are presented, the word wind is repeated 21 times $(22 \%)$, the word rain is repeated 16 times $(16 \%)$ and the word cool is repeated 16 times $(17 \%)$. However, it was determined that other words are repeated 43 times (44\%) in the lullabies (cold, hot, warm, hail, snow, frost, cloud, wind, storm, flood etc.). Climate and weather events can influence people's life positively or negatively. It is seen that children are presented climate and weather events in lullabies from very early ages. These results are significant in that they indicate that the beginning of geography education goes back as early as babyhood period.

Table 7. Time or season related words in lullabies

\begin{tabular}{|c|c|c|}
\hline Word or Concept & $\mathrm{f}$ & $\%$ \\
\hline Spring & 57 & 24 \\
\hline Morning & 41 & 17 \\
\hline Evening & 40 & 17 \\
\hline Other & 98 & 42 \\
\hline Total & 236 & 100 \\
\hline
\end{tabular}

According to Table 7, which shows the frequency of the time or season related words or concepts, the word spring occurs 57 times $(24 \%)$, the word morning is used 41 times $(17 \%)$, and the Word evening is used 40 times $(17 \%)$. However, other time or season related words were used 98 times $(42 \%)$ in the lullabies (summer, winter, day, night, mid-morning, dawn, day, hour, early, late, before noon and afternoon etc.). It is seen that general concepts (spring, morning and evening) related to time and season come forth in lullabies. This situation is attributed to the desire to teach children concept of time and knowledge of seasons.
Table 8. Words and concepts related to location and direction in lullabies

\begin{tabular}{|c|c|c|}
\hline Word or Concept & $\mathrm{f}$ & $\%$ \\
\hline Opposite & 26 & 15 \\
\hline Far & 24 & 14 \\
\hline Close & 22 & 13 \\
\hline Other & 97 & 58 \\
\hline Total & 169 & 100 \\
\hline
\end{tabular}

One of the goals of geography education is to learn the location and direction. Lullabies include basic location and direction concepts.

According to the findings related to the words or concepts related to location and direction given in Table 8 , the Word opposite is used 26 times (15\%), the Word distant is used 24 times $(14 \%)$ and the Word close is repeated 22 times $(13 \%)$ in lullabies. However, it was determined that in the lullabies other location and direction words are repeated 97 times (58\%) (down, up, beyond, near, behind, back, front, side, top, bottom, middle, edge, left, right, east, West, south, north, low, high, swallow, deep and distant and the like). The knowledge of location and direction is one the aims of geography education. Lullabies attract attention as the first steps for teaching this knowledge at early ages. As it can be seen from the findings, it can be said that the location and direction concepts are used frequently in lullabies. In this context, lullabies are of great contribution both for geography education and world knowledge.

Table 9. Words and concepts about mines and precious Stones in lullabies

\begin{tabular}{|c|c|c|}
\hline Word or Concept & $\mathrm{f}$ & $\%$ \\
\hline Copper & 41 & 41 \\
\hline Gold & 20 & 20 \\
\hline Silver & 18 & 19 \\
\hline Other & 20 & 20 \\
\hline Total & 99 & 100 \\
\hline
\end{tabular}

Mining and gemstones are very important resources for people. Many tools are made of this minerals and stones. Mining and economic geography is also involved with aspects of its economic value.

According to the findings related to the words and concepts about mines and precious stones which are used in Turkish lullabies in Table 9, the Word copper is used 41 times $(41 \%)$, the Word gold is used 20 times (20\%) and the Word silver is used 19 times $(18 \%)$. However, it is also determined that names of other mine and precious stones (stone, pearl, diamond, coal etc.) occur 20 times (20\%) in the lullabies. It is considered that children first learn about mines and precious Stones from lullabies. Thus, children's awareness about resources in their environment is developed. In the following process of formal education, it can be argued that children's level of pre-learning about mines and precious stones increase. 
Table 10. Words and concepts related to universe and space used in lullabies

\begin{tabular}{|c|c|c|}
\hline Words and Concepts & $\mathrm{f}$ & $\%$ \\
\hline Sun & 32 & 34 \\
\hline Earth & 22 & 23 \\
\hline Moon & 20 & 21 \\
\hline Other & 21 & 22 \\
\hline Total & 95 & 100 \\
\hline
\end{tabular}

Universe, galaxies, stars, planets and solar system formation fall within the study area of astronomy and geography. Concepts and formations that are directly involved in this aspect of geography are given in table 10 .

According to the findings about the words and concepts in lullabies given in Table 10, the Word sun is used 32 times (34\%), the Word World is used 22 times (23\%) and the Word moon is used 20 times (21\%). However, it was determined that other universe related expressions are used 21 times (22\%) (The Pleiades, the Venus, the Milk Way, universe, star and the like...) in lullabies. It is seen that among universe and space related words in lullabies, the words earth, sun and moon come to the forth. Accordingly, it can be considered that children are informed about universe and space to convey them the message that we are a part of a large system. Thus, it can be argued that children develop consciousness about universe and space.

Table 11. Agriculture and Husbandry Related words and concepts in lullabies

\begin{tabular}{|c|c|c|}
\hline Word or concept & $\mathrm{f}$ & $\%$ \\
\hline Calf & 210 & 24 \\
\hline Orchard & 208 & 23 \\
\hline Field & 86 & 10 \\
\hline Other & 386 & 43 \\
\hline Total & 890 & 100 \\
\hline
\end{tabular}

Agriculture; is a collection of technical sciences, can be defined as obtaining animal and vegetable products and having aspects with biological, social and economic environment. All activities related to agriculture covered by the economic geography. Various concepts related to agriculture were reflected in lullabies.

According to findings about agriculture and husbandry related Words in lullabies in Table 11, the Word calf is used 210 times (24\%), the Word orchard is used 208 times (\%23), the Word field is used 86 times (10\%). However, it was found that other agriculture and husbandry related words or concepts were used 386 times (40\%) (plow, crop, harvest, plough, ox, cow, mutton, goat, barley, wheat, seed storehouse, haymow, cultivation, mow, seed, cutting firewood, herd mutton, yoghurt, milk, cheese, slurry, fold, kid, foal, lamb, horse, donkey, colt, shovel, pickaxe, axe, hatchet, reaping-hook, scythe, onion, garlic etc.). In general, people in the country make a living in agriculture and husbandry. Therefore, expressions about agriculture and husbandry are used frequently in lullabies. It can be said that educational principles from close to distant (village-town-region and country) and from known to unknown are used in lullabies. It can be said that this gives children opportunities to learn and get acquainted with economic activities in their close environment.

\subsection{Findings and Interpretations with Regard to the Second Sub-problem}

The second sub-problem of the study is "How are these concepts and words presented to children?" To answer this question, the lullabies in which geography related words and concepts mentioned above are seen, were analyzed with descriptive discourse analysis. Descriptive discourse analysis is a kind of analysis which does not involve in criticism and based solely on the text [16].

First of all, as lullabies are sung to children in a period before they start talking, with lullabies children start familiarizing with outer world and society before they learn about them. This period of familiarization starts with giving children some words and concepts.

In general, when the distribution of words about geography is considered, some characteristics strike to the eye, which can be listed as follows:

a) First all, information is presented from close to distant. Starting from his/her cradle, the child learns about the room, home, street, nomad camping site, that is, s/her learns close and distant environment. In other words, educational principle of "from close to distant" is used in lullabies.

b) In general, children are presented information in his/her immediate environment which s/he can encounter with concrete experience. There are words which give him/her chances to interaction with a phenomenon or situation, animal, land form or vegetation in his/her immediate environment. For example, the names of animals like calf, lamb or mutton which are present in the immediate environment are used frequently, lion is used very rarely. There are also many words related to agriculture because agriculture has been the most important means of livelihood in Turkish society.

c) While a lot of words are used for the introduction and description of the immediate environment, relatively fewer words are used to introduce and define distant places. While a house or animal in the immediate environment is told in detail, there are few words or information about the earth, sun or stars.

d) The words and concepts used in lullabies generally involve the kind of knowledge accumulated, filtered and repeated through observation for years. It is not very much based on encyclopedic or field knowledge.

In the lullabies given below, it is possible to see how some geography related terms are presented. Examples were taken 
from Demir \& Demir [10].

Sample 1

\author{
"It gets dark in the evening, sleep \\ It clears up again in the morning, sleep, \\ My little lamb \\ Picks up apple from the branch, sleep, \\ Say Sleep and get to sleep, \\ So that your dad comes from foreign lands". \\ (Ayşe Söğ̈ut, Mersin: 348)
}

In this lullaby the concepts of evening, morning and foreign land are presented. It is stated that it gets dark in the evening and in the morning it clears up and they follow each other, and Word "gurbet" (foreign lands) is identified with the concept of distance and mentioned as a distant place where people come back. Besides, the words apple and branch and their relation are presented.

\section{Sample 2}

\author{
"Sleep my honey sleep \\ Sleep my lamb sleep \\ My rose be your ball my son \\ May your wedding held \\ Under green pines". \\ (Gülümser Şerbet, Bitlis:104)
}

In this lullaby, relations between rose, green pine and wedding ceremony are established. As wedding ceremony is the happiest day of an individual, environment and trees are emphasized with elements of green pine and rose.

\section{Sample 3}

\author{
"The wells of Istanbul \\ Its sides are full of meadows \\ His uncles come from hunt \\ Sleep my little one sleep”. \\ (Kezban Yllmaz, Afyon:104)
}

In this lullaby, Istanbul, which is very important city in Turkish culture, is mentioned with its greenery, shore and wells. Besides, hunting as a habit is emphasized.

\section{Sample 4}

\section{"Rose blossoms in the garden \\ Gazelle runs away in the mountains My little one smiles \\ Roses blossom on his face. \\ Spring comes and then summer comes \\ Cranes comes and then ducks come Cubes of Gold \\ Is not enough for my daughter". (Perişan Şahin, Ăgrl:107)}

In the first stanza of this lullaby, the words mountain, gazelle, rose, garden are used when the relations between rose and garden, gazelle and mountain are presented. In the second stanza, the relations between the spring and summer, and the relation between cranes and time are presented. While the summer comes after the spring, migratory cranes and ducks return back in these seasons. Besides, it is allusively indicated that gold is a precious metal used for shopping.

\section{Sample 5}

\author{
The mountains over there, high mountains \\ The mountains surrounded with waters \\ Sleep my little one sleep \\ Sleep my lamb \\ (Durmuş Yokuş, Sivas:144)
}

In this lullaby, information about the distribution of mountains and waters is presented. In Anatolia, there is a stream or a lake nearby mountains. This information is transferred to children in this lullaby.

\section{Conclusion, Discussion and Suggestions}

In this study, the words and concepts related to geography children learn in lullabies are examined in the context of Turkish culture and sample chosen. The following results have been reached as a result of the study which employed both quantitative and qualitative techniques:

a) Lullabies as a significant cultural means of education allow children to be acquainted with geography related words and concepts from their birth.

b) Geography related words and concepts in lullabies are presented from close to distance and from concrete to abstract.

c) Lullabies present children their immediate environment with both social and natural point of view.

d) Words and concepts are presented in relation. These relations of contrasts, similarities, superiority, inferiority etc. facilitate the retention of these words and concepts in child's mind.

e) To the extent that it is possible, words and concepts which can children use to interact are chosen in lullabies.

In sum, lullabies enable children to encounter, perceive and learn many words and concepts related to geography before they come to school. Besides providing information and consciousness about the environment, lullabies provide children with geographical knowledge and navigations skills. In this respect, the lullabies that children start hearing in the periods when they are not linguistically developed adequately are very important cultural sources in transmitting the culture of a country and in presenting children words, concepts and information about specific and life related disciplines like geography.

In their studies Uğurlu [31], Güneş \& Güneş [15] examined the roles of lullabies in transmitting culture and their effects of children. In these studies, they determined 
that lullabies facilitated the acquisition of some knowledge and cultural elements that they can use in their future lives. Even though this study studies lullabies in the context of geography related words and concepts, it has been determined that lullabies make undeniable contributions to children's knowledge in this discipline.

In another study, Demir \& Oflaz [11] examined the contributions of lullabies to mathematics education. In the study, it was determined that children are acquainted with many basic concepts in mathematics through lullabies. The findings of this study which indicate that lullabies have contribution in the acquisition of geography related words and concepts are in parallel with the findings of the study their study, they are in different disciplines tough.

In another study by Demir [9], the use of lullabies in teaching Turkish and Turkish culture to the children of the families living in Europe was examined and lullabies were suggested as effective educational materials for teaching children aged between 0 and 6 . This study which found similar results supports the results of Demir's study.

The collection examined in this study is composed of 3800 lullabies. It is suggested that further studies use larger collections and different techniques to analyze them. In this way, lullabies as cultural elements will be recorded and preserved, and their educational and scientific values will be revealed.

Collections of lullabies are to be developed for children and parents, especially for mothers or expectant mothers and everyone should be allowed to benefit from this treasure of culture. As very precious elements of culture and literature through which language and information are introduced to children for the first time, they are to be collected, recorded and presented to the use of people and researchers.

\section{REFERENCES}

[1] Arseven, A. The Reggio Emilia Approach and Curriculum Development Process. International Journal of Academic Research. 6(1), 166-171, 2014. Doi: 10.7813/2075-4124.201 4/6-1/B.23.

[2] Aksan, D. Dilbilim ve Türkçe Yazıları, Multilingual Yayınları, İstanbul, 2004.

[3] Aydın, A. Gelişim ve öğrenme psikolojisi, Alfa Basım Yayın. İstanbul, 2000.

[4] Aydın, A. Eğitim psikolojisi (gelişim-öğrenme-öğretim), Pegem Akademi. Ankara, 2010.

[5] Barth, J. \& Demirtaş, A. İlköğretim sosyal bilgiler öğretimi. YÖK/Dünya Bankası Milli Eğitimi Geliştirme Projesi, Öğretmen Eğitimi Dizisi, Ankara, 1997.

[6] Berelson, B. Content analysis in communication research. Glencoe, III: Free Press, 1952.

[7] Cooper, R. P., \& Aslin, R. N. Preference for infant-directed speech in the first month after birth. Child Development, 61,
1584-1595, 1990. Doi: 10.1111/j.1467 8624.1990.tb02885.x

[8] Çelebioğlu, A. Türk ninniler hazinesi. Kitabevi Yayınları, İstanbul, 1995.

[9] Demir, N. Avrupa'da yaşayan 0-6 yaş grubu Türk çocuklarına Türkçe ve Türk kültürünün öğretilmesinde kullanılabilecek bir materyal: Türk ninnileri. The Journal of International Social Research, 1(5), 224-240, 2008.

[10] Demir, N. \& Demir, F. Türk ninnileri (3. Bask1), Edge Akademi Matbaası, Ankara, 2014.

[11] Demir, N., \& Oflaz, G. Okul öncesi dönemde ninniler ile matematik öğretimi.Zeitschrift für die Welt der Türken Journal of World of Turks (ZfWT). 2(1), 353-362, 2010.

[12] Ertürk, S. Eğitimde program geliştirme. Meteksan Yayınevi, Ankara, 1994.

[13] Girgin, M. Neden coğrafya öğreniyoruz? Doğu Coğrafya Dergisi, 7(5), 127-143, 2001.

[14] Güneş, F. Ninnilerin çocukların dil ve zihinsel gelişimine etkisi, Journal of World of Turks, 2(3), 27-38, 2010.

[15] Güneş, H \& Güneş, N. The effects of lullabies on children. International Journal of Business and Social Science, 3(7), 316-321, 2012.

[16] Gür, T. Post-modern bir araştırma yöntemi olarak söylem çözümlemesi. Zeitschrift fürdie Welt der Türken, 5(1), 185-202, 2013

[17] Honig, A. S. The art of talking to baby. Working Mother, 8(3), 72-78, 1985.

[18] Honig, A. S. Singing with infants and toddlers. Young Children, 50(5), 72-78, 1995.

[19] Honig, A. S. Communicating with babies through music and song. Scholastic Early Childhood Today, 18(5): 24-27, 2004.

[20] Kabadayı, A. Ninnilerin çocuğun gelişim alanlarına katkılarının içerik açısından incelenmesi: Konya örneği. Uluslararası İnsan Bilimleri Dergisi, 5(1), 276-289, 2009.

[21] Kavcar, C. Edebiyat ve eğitim, Engin Yayınevi, Ankara, 1999.

[22] Kaya, D. Anonim halk şiiri. Akçağ Yayınevi Ankara, 2004.

[23] Krippendorff, K. (1980). Content analysis: an introduction to 1ts methodology. Sage, Newbury Park,CA, 1980.

[24] Kvalseth, T. O. Note on Cohen's kappa. Psychological reports, 65(1), 223-226, 1989. Doi:10.2466/pr0.1989.65.1.223

[25] Landis, J.R., \& Koch, G.G. The measurement of observer agreement for categorical data. Biometrics, 33(1), 159- 174, 1977. Doi: $10.2307 / 2529310$

[26] Lickteig, M. J., \& Danielson, K. E. Use children's books to link cultures of the world. The Social Studies, 86(2),69-73,1995. Doi: 10.1080/00377996.1995.9958373

[27] Poyraz, H. Okulöncesi eğitiminin ilke ve yöntemleri. Anı Yayınları, Ankara, 2003.

[28] Senemoğlu, N. Gelişim öğrenme ve öğretim (kuramdan uygulamaya). GaziKitabevi, Ankara, 2001.

[29] Stacey, M. Methods of social research. Pergamon Press, Oxford, 1970. 
[30] Tuğrul, B., \& Duran, E. Her çocuk başarılı olmak için bir şansa sahiptir: zekânın çok boyutluluğu çoklu zekâ kuramı. Hacettepe Eğitim Fakültesi Dergisi, 24, 224-233, 2003.

[31] Uğurlu, E. K. Kültürel bellek aktarıcısı olarak ninni. Millı Folklor, 26(102), 43-52, 2014.

[32] Ünlü, M. İlköğretim okullarında coğrafya eğitim ve öğretimi. Marmara Coğrafya Dergisi, 3(2), 31-48, 2001.

[33] Trehub, S. E., \& Trainor, L. J. Singing to infants: Lullabies and play songs. Advances in Infancy Research, 12, 43-77, 1998.
[34] Tsang, C. D., \& Conrad, N. J. Does the message matter? The effects of song type on infants' pitch preference for lullabies and play songs. Infant Behavior and Development, 33, 96-100, 2010. doi:10.1016/j.infbeh.2009.11.006

[35] Weber, R. P. Basic content analysis (2nd ed). CA, Newbury Park, 1990

[36] Wheelock, A., Bebell, D. J., \& Haney, W. What can student drawings tell us about high-stakes testing in Massachusetts? Teachers College Record [Online]. Available: www .tcrecor d.org/Content/asp?ContentID=10634, 2000. 